\title{
Motives and Forms of Secondary Employment in the Field of Higher Professional Education of the District Murom
}

\author{
N.V.Smolina*, M.N. Ryzhkova \\ Murom Institute (branch) of Vladimir State University, Murom, 602254, Russia \\ *Corresponding author. Email: smolinanv@bk.ru
}

\begin{abstract}
The article describes the basic motifs of secondary employment, its relationship with the main profession, some features of secondary employment in the field of higher professional education the Vladimir region. An analysis of the content has been shown, as well as the specific of operation on secondary employment of education workers in small provincial towns. The relevance of the topic is related to a change in the lives of people in small towns, the changes in connection with the employment of their residents, so that the foreground are increasingly in precisely the socio-economic problems. The article has been ambiguous role of secondary employment in modern economic relations.

Keywords: secondary employment, education, motives of secondary employment, forms of secondary
\end{abstract}

\section{employment}

Modern Russia is characterized by a low level of wages, in which wages of the high skill level is slightly above the subsistence level. Salaries of teaching staff of higher educational institutions reflect a society's attitude to education, and the status of the University teacher, regarding his socio-economic situation in our country is far from meeting international standards. Pedagogical personnel of higher professional education represent the exceptional category of the employed population of Russia, as among them, a very high proportion of those who have a second job[1].

Despite the widespread use of the term "secondary employment" at the present time there is no generally accepted and unambiguous interpretation. Roshchin S.Y., Razumova T.O. secondary employment is determined as work more than one job. In this case, the subjects of relations of employment are only those who are already engaged in social production[6].

E.Y. Varshavsky believes that this approach greatly simplifies the situation in the employment sector, as it is widely known that many pensioners, students, unemployed (regardless of their formal status) engaged in domestic or personal farms, sometimes moonlighting[3]. Some authors (E.A. Khibovskaya[7], E.V. Klopov[4]) understand under such secondary employment that is associated with obtaining additional cash income. The source may be work on your own or other enterprises or organizations.

The functioning of the professional group "teacher University" linked to the rise in the last decade a contradiction: on the one hand, this group has a high mission in the information society, significant educational potential, and, on the other - the low level and quality of life, and as a result inclusion of this category of workers in the sphere of secondary employment[2]. This contradiction leads to the misalignment of the main status professional groups, reducing the effectiveness of its work.

In a market society the place of professional activity of workers of sphere of education is between the utilitarian and market-based and educational functions, with a small deviation in favor of the latter. By and large, a teacher has ceased to be an educator, but has not yet become a market economy[5]. There is a direct correlation: the higher the job status of the teacher, the less he identifyees himself with the execution of the function of the teacher-educator (associate professors and professors often identify themselves with "the seller of educational services").

The survey covered workers of higher professional education of Murom (MIVISU and SAG) in the amount of 100 people. Respondents were asked to "questionnaire for the study of forms and motives of participation in secondary employment of educators small provincial town".

Studying axiological aspects of professional activities, we asked teachers to assess the benefits that now keep them on the job.

The core values that hold today of high school teachers in their profession, consists of free graphics work and creative nature of the activity (these professional characteristics are important to more than half of the teaching staff).

Building specific patterns of behaviour in real practice, a quarter of teachers prefers the preparation of new generations of young professionals ("teachers of life"), and another quarter obtaining scientific results ("intellectuals"). The remaining $50 \%$ value in the professional employment of the non-core value-semantic components, and secondary (schedule, changing nature of work, social circle, the opportunity to earn additional income); the labour behavior, they often adhere to models of "multi-tasking machine operator" - do a bit of everything 
On the survey question "How regularly did You engage in part-time work?" $44 \%$ of respondents said constantly (over several years); $56 \%$ - are regularly (periodically); 39\% from time to time (occasionally) and only $7 \%$ have never engaged in part-time jobs, in addition to the main activities.

Table 1 Representation of University teachers on the meaning of profession (in \%)

\begin{tabular}{|c|c|c|c|c|c|c|c|c|c|c|c|c|}
\hline & \multirow[t]{2}{*}{ Just } & \multicolumn{4}{|c|}{ The post } & \multicolumn{7}{|c|}{ The profile of the Department } \\
\hline & & 荀 & के & 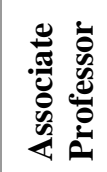 & 宫 & 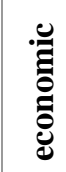 & 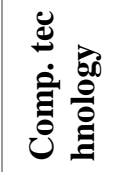 & 它晜䒿 & 를 & 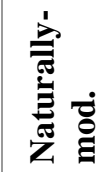 & ్ㅐㅇ & 氞 \\
\hline \multicolumn{13}{|l|}{$\begin{array}{l}\text { Values of a } \\
\text { profession }\end{array}$} \\
\hline $\begin{array}{l}\text { Creative } \\
\text { activities }\end{array}$ & 50 & 44 & 45 & 55 & 56 & 37 & 59 & 63 & 54 & 42 & 24 & 41 \\
\hline $\begin{array}{l}\text { The } \\
\text { possibility of } \\
\text { additional } \\
\text { earnings }\end{array}$ & 21 & 24 & 26 & 19 & 10 & 31 & 14 & 18 & 18 & 28 & 26 & 9 \\
\hline $\begin{array}{l}\text { Conditions } \\
\text { for } \\
\text { professional } \\
\text { career }\end{array}$ & 21 & 15 & 26 & 18 & 23 & 19 & 14 & 24 & 14 & 11 & 43 & 34 \\
\hline $\begin{array}{l}\text { Involvement } \\
\text { in the } \\
\text { training } \\
\text { young } \\
\text { professionals }\end{array}$ & 24 & 24 & 22 & 21 & 34 & 24 & 14 & 24 & 28 & 23 & 21 & 16 \\
\hline $\begin{array}{l}\text { Prestige in } \\
\text { the eyes of } \\
\text { the middle } \\
\text { environment }\end{array}$ & 8 & 13 & 9 & 7 & 4 & 15 & 0 & 9 & 7 & 8 & 14 & 3 \\
\hline $\begin{array}{l}\text { Flexible } \\
\text { schedule }\end{array}$ & 54 & 55 & 52 & 59 & 37 & 52 & 57 & 52 & 54 & 66 & 43 & 53 \\
\hline $\begin{array}{l}\text { A wide circle } \\
\text { of friends }\end{array}$ & 20 & 25 & 24 & 17 & 14 & 19 & 16 & 18 & 22 & 19 & 21 & 28 \\
\hline Wages & 7 & 10 & 7 & 7 & 4 & 13 & 8 & 6 & 8 & 4 & 10 & 0 \\
\hline $\begin{array}{l}\text { Self- } \\
\text { realization } \\
\text { in science }\end{array}$ & 26 & 35 & 17 & 22 & 44 & 32 & 32 & 30 & 20 & 32 & 21 & 6 \\
\hline Job security & 20 & 15 & 21 & 24 & 14 & 19 & 24 & 22 & 18 & 19 & 19 & 28 \\
\hline
\end{tabular}

As shown by the results of the study, a significant part of teachers of higher educational institutions has additional work. For many of them this secondary employment - primarily a source of additional income, as in education now time income is very low. The number of teachers who have additional earnings, is distributed as follows: doctor of Sciences, Professor - 56\%; candidates of Sciences, associate professors -75,3\%; senior lecturers -81,8\%; assistants $87,2 \%$. 


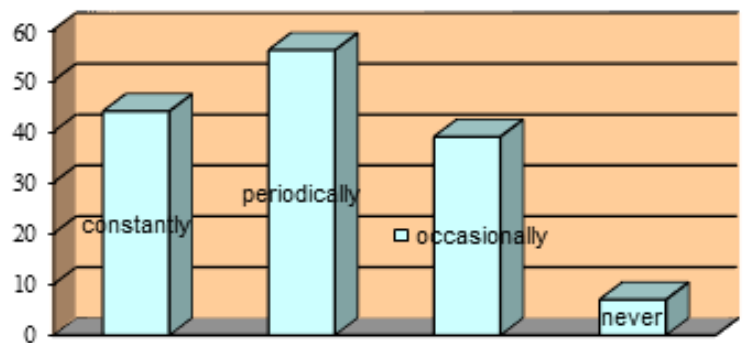

Figure 1. The distribution of respondents ' answers to the survey question «How regularly did You engage in part-time work?" Source: compiled by the author based on research results.

You can highlight the main form of secondary employment in education: teaching in the basic place of work on a commercial basis; teaching at other educational institutions (universities, high schools, schools, private teaching; research work in universities; work in commercial organizations; business activities

The types of secondary employment are determined by the professional affiliation of respondents University teacher. Therefore, the faculty characteristic of "part" in their own University, especially in teaching activities on a commercial basis, with extrabudgetary academic groups of full-and part-time training. Further, for departments not characteristic of secondary employment in high schools, schools: this is a work in specialized classes (15\%), organization of preparatory courses in mathematics, physics, computer science (18\%). Departments are engaged in research work at the University, actively search for and enter into contractual research with various companies and structures. Work in commercial organizations and business activities are not the usual types of secondary employment for high school teachers, but are present as a kind of "survival niches". It can be argued that a significant proportion of the faculty used by the Institute to perform work similar to that of their main occupation. In other words, the additional employment is often the natural continuation of the employment in the main workplace. Thus, the deprofessionalization in the sphere of secondary employment employees of the University are mostly not experience.

Secondary employment employee's education is manifested in the combination of research activities with teaching and tutoring work, and the execution of various orders "from outside" and participation in various programs. Many combine their work with consultancy services. All this confirms one of the most painful social problems in Russia - the lack of demand on the primary labour market specialists with high qualifications.

In small provincial towns there are the following national trends changes in the socio-professional status of educators: - deterioration of the socio-demographic characteristics of teaching staff (aging, feminization, low degree of rotation of teaching staff mobility);

multiple secondary occupation teachers (part-time not only jobs but also a wide spectrum of taught courses);

- increase the number of teacher's high schools that I think it is possible without the teaching of scientific work;

- General decline in the quality of scientific and pedagogical the Russian Universities - an outflow of talented teachers in the commercial, political or power structure.

\section{REFERENCES}

[1] Abram E. M. Social mobility in the conditions of Russian crisis, Public Sciences and modernity. 1999. No. 3.

[2] Bulgakov, S. V., Secondary employment in contemporary Russia: socio-economic functions and consequences. Abstract the dessert. Saratov, 2004.

[3] Varsawskaya E. J. Secondary employment: issues of theory and practice, Avtoref. dis, M., 2007.

[4] Klopov E. V. Secondary employment as a form of socio - labor mobility, Sociological researches, 1997, No. 4. S. $29-42$

[5] Presnyakov M. V. Moonlighting and reconciliation: problems of legislative regulation and law enforcement practices, Labor law. - 2009. - No. 2. With 45-49

[6] Razumova T., Roshin S. Economic analysis of factors of secondary employment, economy Questions. 2001. No. 9. p. $130-140$

[7] Khibovskaya E. A. Secondary employment in various sectors of economy, the Economic and social changes: monitoring public opinion of 1996. - No. 3. 